\title{
PATRONAGE DIVIDENDS: INCOME DISTRIBUTION OR PRICE ADJUSTMENT
}

\begin{abstract}
Albert W. Adcock*
One of the most controversial issues before the public today concerns the application of the federal income tax to cooperative corporations. In full-page newspaper advertisements, radio round-table discussions, magazine articles, and newspaper editorials are found discussions of this subject. It is on the agenda of the House Committee on Small Business, which is interested in the question whether cooperative corporations have any unfair competitive advantages over private corporations. It is on the agenda of the House Ways and Means Committee, which is interested in the income of cooperative corporations as a possible source of additional revenue.

A cooperative corporation does not pay the same income taxes that a private corporation doing a similar amount of business with the same efficiency pays. The reason for this difference is the subject of the present controversy.

Cooperative leaders maintain that they merely adjust their prices at the end of the year, with the result that their business is done at cost. Private business, on the other hand, maintains that cooperatives do business at a profit and then, in accordance with their by-laws, distribute this corporate profit to their patrons on the basis of their patronage.

A corporation doing business at cost has no income. Therefore, if the cooperatives are correct in their contentions, no one can rightfully complain if they pay no income taxes. If, however, cooperative corporations are distributing net income instead of adjusting prices when they pay their patronage dividends, there is a grave injustice in the present tax treatment of the patronage dividends of cooperative corporations.
\end{abstract}

\section{I}

Some cooperative corporations are organized under the business corporation acts of the various states. Since they earn their profits in the same manner as any other business corporation, no special knowledge as to the nature of their profits when they are distributed as patronage dividends can be obtained from studying the laws under which they are incorporated.

The same is not true with respect to cooperatives which are organized under the cooperative laws of their respective states. These corporations must operate within the framework of the laws under which they are organized, and much light can

- B.S. 1932, M.A. 1933, J.D. 1936, Northwestern University. General Counsel for National Tax Equality Association. 
be thrown on this controversy by a study of the laws to see whether such corporations do bùsiness on a cost basis or whether they earn profits which they distribute to their stockholder-patrons in the form of dividends on stock and on patronage.

A better understanding of the nature of the patronage dividend will be obtained if the cooperative financial statement is first examined. Although the terminology may be different from that used by ordinary corporations, the steps taken are identical.

From gross receipts the cooperative corporation deducts the cost of goods sold and necessary operating expenses. The result, with a few adjustments, is the corporate net profits, which the cooperative sometimes labels net margins, net savings, net over-deposits, etc. A part of these net profits (or net savings, as cooperatives often call them) is usually put into surplus, and another part is often credited to an educational fund. The remainder of the net profits is distributed to the corporation's group of stockholder-patrons in the form of dividends on capital and on patronage.

The laws under which cooperative corporations are organized and the by-laws of most such corporations customarily recognize that these corporations make profits, and that out of such profits dividends on capital stock may be paid. The remaining profits, if any, are then available for distribution as patronage dividends.

The statutory language used in representative states concerning the final distribution of these remaining profits is as follows:

\section{North Dakota:}

Directors to Apportion Earnings: Dividends; Reserves; Patronage Dividends. . . . The remainder of the net earnings shall be prorated by a dividend upon the amount of purchases or sales of raw material or both of stockholders. ....

\section{Minnesota:}

Net income in excess of dividends on capital stock and additions to reserve and surplus shall be distributed on the basis of patronage. ${ }^{2}$

Illinois:

... net income in excess of additions to reserves and surplus so established, shall be distributed to the members of the association on the basis of patronage. ${ }^{3}$

\section{Michigan:}

The Michigan Cooperative Corporation Law discusses the provisions in by-laws providing for patronage dividends by cooperative corporations organized thereunder: Said by-laws shall further provide . . . in what manner, method and proportion the surplus annual earnings and profits of the business of such corporation, in excess of such dividends and reserve fund, shall be divided up and distributed as a cooperative dividend, under the cooperative plan or principle....

1 N. D. Rev. CODE 5 ro-1520 (1943).

2 Minn. Stat. ANn. \$308.12.

Il.L. Stat. ANN. c. 30.46, \$I5.

-The General Corporation Act, Mich. Comp. LAws \$10035, c. 195. 
New York:

Under the New York Cooperative Corporation $\mathrm{Law}^{5}$ the members of the corporation may be divided into two classes. Members of the first class include common stockholders and may include employees. Members of the second class include non-stockholder patrons for whom the corporation does business amounting to at least $\$ 100$ during any fiscal year. ${ }^{6}$ The law deals with patronage dividends in Section 93, which reads in part as follows:

Earnings; dividends. . . . The remainder of the net earnings, may in the discretion of the directors be distributed by uniform dividend to members of the first class and members of the second class.?

\section{Florida:}

... net income in excess of additions to reserves and surpluses so established, shall be distributed to the members of the association on the basis of patronage. Any distribution of reserves and surpluses at any time shall be made to members at the time such distribution is ordered on the basis of patronage.

Any receipts or dividends from subsidiary corporations or from stock or other securities owned by the association shall be included in the ordinary receipts of the association. 8

Statutes from other states follow the same design.

It thus appears that patronage dividend rights are similar to the rights of holders of an inferior grade of stock and are payable only out of the profits remaining after the preferred and common shareholders have been paid their dividends.

In Minnesota, the Commissioner of Agriculture proposed the following question to the Attorney General with respect to cooperative corporations:

Is it mandatory upon an association organized under Chapter 23, Laws of 1923, to pay a dividend on capital stock before a portion of the net earnings can be distributed as patronage dividends?

The Attorney General answered the question as follows:

Yes. The law is not as clear as it might be in respect to this, but I think such mandatory character is disclosed by the general provisions of the law.

From these, it appears that the intent was that capital stock should receive a dividend before a patronage dividend should be declared, and I so hold.

The Commissioner also asked what would govern the rate of dividend to be paid on the capital stock, and the Attorney General answered:

If the earnings are such as to justify them in declaring an eight per cent dividend, I think it is the intent of the law that they should do so, and they cannot arbitrarily under such circumstances declare a smaller dividend. ${ }^{9}$

${ }^{8}$ N. Y. CoOp. Corp. LAw.

'Id. $\$ 93$, as amended by c. 383 , Laws of 1932 .

- rog Ops. Att'y Gen. Minn. I24 (I922).
Id. $\$ 85$.

Fla. Stat. ANN. \$6I8.I5. 
It should be noted that the state laws do not direct cooperative corporations to do business on a cost basis, or even to pay additional prices or give rebates which would result in doing business on a cost basis. They direct the corporation to distribute its profits according to a certain pattern. When the corporation, in obedience to the law, distributes its profits in that fashion, it is, beyond question, making a distribution of its profits and not making a price adjustment or rebate. This holds true regardless of the name given to the corporate profits. Calling them "net savings" does not change the fact that they are profits earned by the corporation.

If the cooperatives believed that they had no net earnings or net profits, and that by means of rebates and price adjustments they did business on a cost basis, one would expect their by-laws to reflect that fact. The by-laws could do so if that were the way in which cooperatives did business; however, since they do business at a profit, that is the fact reflected in their charters and by-laws.

For example, the by-laws of one cooperative corporation provided:

Profits shall be divided among stockholders as follows: Not to exceed 8 per cent on the paid up capital and the balance of profits, if any, shall be divided among the members, according to the amount of business they have transacted with the association, but first not less than 5 per cent shall be added to the educational fund and xo per cent to the surplus. ${ }^{10}$

The Farmers Cooperative Association case ${ }^{11}$ involved a Kansas cooperative corporation. An answer to the question whether its members received corporate profits by way of patronage dividends may be found by reading Article $\mathrm{X}$ of its corporate charter:

Article X-Net Profits. The net approximate profits of the business shall be paid to the members of the association at the close of each year after having been prorated on the amount of their purchases or sales, for, or by themselves or families during the year. ${ }^{12}$

The above examples are enough to indicate the pattern which the charter provisions and by-laws of cooperative corporations customarily follow. ${ }^{13}$ They usually provide, first of all, that a certain percentage of the net profits of the corporation shall be used to set up surplus reserves; that thereafter dividends shall be paid on capital stock; and finally that the remainder of the net profits shall be distributed as patronage dividends.

\section{II}

The leaders of the cooperative movement maintain that cooperative corporations, by means of patronage-dividend price adjustments, in effect do business at cost, and that therefore, since they earn no profits, the question of taxing their profits

${ }^{20}$ ARR 6967, III-I CUM. BULL. 287 (1924). (Italics supplied.)

215 B.T.A. 6I (1926).

12 Similar charter provisions and by-laws of cooperative corporations may be found in the following cases: Sacred Heart Cooperative Mercantile Co., 2 B.T.A. 24 (Ig25); Trego County Cooperative Ass'n, 6 B.T.A. 1275 (1927); Farmers Union Cooperative, 13 B.T.A. 969 (I928); Midland Cooperative Wholesale, 44 B.T.A. 824 (I94I); Farmers Union Cooperative Co. v. Commissioner, 90 F. $2 \mathrm{~d} 488$ (C.C.A. 8th I937); Cooperative Oil Ass'n v. Commissoner, Irs F. 2d 666 (C.C.A. 9th 1940). 
cannot arise. When the courts are faced with this issue, however, they are not satisfied with the fact that a patronage dividend is superficially like a price adjustment. They study the way in which the corporation operates and the way in which the monies it distributes are earned.

In Storen v. Jasper City Farm Bureau Co-operative Association ${ }^{14}$ the cooperative association claimed exemption from the state gross income tax. That the court regarded patronage dividends as distributions of income rather than as price adjustments clearly appears from the following language taken from its opinion:

The profit or any gain made as a result of the carrying on of a business of buying and selling has in recent years, under both federal and state net income tax acts, been held to be income. The gain made here was made in the conduct of ${ }^{\circ}$ a purely commercial business which consisted of making purchases and sales. The difference in the cost of the appellee and its sales price to the purchaser was a profit, gain, or income and thus inured to the ... patrons of appellee. ....15

In Schuster v. Ohio Farmers' Co-operative Milk Association ${ }^{16}$ the cooperative maintained that it did not engage in business for a profit. The circuit court of appeals answered this argument as follows:

Obviously, the cooperative marketing association is organized for profit in the sense of financial benefit to its members. The element of departure from ordinary corporate economic practice is found in the fact that the financial gain is enjoyed by the members in proportion to the production, by each, of the products handled, rather than in proportion to the capital otherwise contributed by each to the conduct of the business; but this difference of economic principle governing the distribution of wealth cannot alter the fact that the sole incentive to membership in such an association is the financial benefit to be derived therefrom in the marketing of the farm products which the member is producing. 17

Sometimes cooperative spokesmen contend that, even though the cooperative corporation does make a profit, since it is a cooperative corporation as distinguished from a capitalistic corporation its profits belong to its members and cannot be taxed to it. This argument was used in Penn Mutual Life Insurance Company $v$. Lederer. ${ }^{18}$ In holding that the mutual corporation was taxable on its profits, the Supreme Court said:

The fact that the investment resulting in accumulation or dividend is made by a cooperative as distinguished from a capitalistic concern does not prevent the amount thereof being properly deemed a profit on the investment. ${ }^{18}$

In Farmers Oil Company v. State Tax Commission 20 the plaintiff was a cooperative company selling gasoline and fuel oils to its members, all of whom

14 103 Ind. App. 77, 2 N. E. 2d 432 (1936).

${ }^{18} \mathrm{Id}$. at 434. (Italics supplied.) See also Diekmann v. Evansville Producers Commission Ass'n, 219 Ind. 636,40 N. E. 2d 327 (1942).

${ }^{10} 6 \mathrm{I}$ F. $2 \mathrm{~d} 337$ (C.C.A. 6th 1932).

18252 U. S. 523 (1920).

${ }^{10}$ Id. at 534. See also Frost v. Corporation Commission of Oklahoma, 278 U. S. 515 (I929), holding that a cooperative corporation is in business for profit.

${ }^{20} 4 \mathrm{I}$ N. M. 693,73 P. $2 \mathrm{~d} 8 \mathrm{I} 6$ (1937). 
operated farms and ranches. The corporation claimed that it had no profits and merely assisted its members to obtain supplies at a low cost. In considering the argument of the cooperative, the court noted that, while the business corporation earns profit as an entity, the profit is destined to go to the stockholders in the form of dividends. Similarly, the cooperative corporation earns profit as an entity and distributes it to patrons. The court said:

The mere fact that plaintiff makes the volume of purchases from it by members, rather than the number of shares owned, the measure of their gain in no wise alters the fact that it, as well as its members, receives benefit and advantage in thus fulfilling the very purpose of its corporate existence. ${ }^{21}$

If patronage dividends were, in fact, rebates or additional payment of price, the tax consequences of paying them would in all cases be the same as if the adjusted price had been the one originally paid. The courts, however, do not accept this theory.

Further light on the nature of the patronage dividend can be found in its treatment under the NIRA. ${ }^{22}$ The NIRA and its codes was designed to stabilize prices and to prohibit the various trade discounts, rebates, and price adjustments customarily used in business. ${ }^{23}$ In as much as some Treasury rulings had loosely referred to patronage dividends as rebates, there was a question whether the NIRA and its codes prohibited the payment of patronage dividends by a cooperative corporation. Since legitimate cooperative corporations distribute actual earnings to their patrons as patronage dividends and do not give them any rebates or price adjustments, the President, on October 23, I933, issued Executive Order No. 6355 , in which he ordered:

... that no provision in any code of fair competition, agreement, or license which has heretofore been or may hereafter be approved ... shall be so construed or applied as to prohibit the payment of patronage dividends in accordance with law to any member by any bona fide and legitimate cooperative organization, including any farmers' cooperative, duly organized under the laws of any State, Territory or the District of Columbia or of the United States, if such patronage dividends are paid out of actual earnings of such cooperative organization and are not paid at the time when such member makes a purchase from such cooperative organization. ${ }^{24}$

It was of course possible for the cooperative corporations to give rebates to their members as patronage dividends and thus violate the NIRA and its codes. The Executive Order, however, made it clear that no rebate was being given and so no code provision was being violated if a true patronage dividend, i.e., a distribution of actual earnings, was made to the members of the corporation.

Just as the essential nature of the patronage dividend kept it from being classed as a rebate and so prohibited under the provisions of the NIRA, so also did its essential nature keep it from being regarded as a rebate prohibited under the

${ }^{21} I d$. at $8 \mathrm{r} 8$.

${ }^{2 *} 48$ STAT. 295 (1933).

is Ibid.

st Exec. Order No. 6355, Oct. 23, 1933. (Italics supplied.) 
Robinson-Patman Act. The Robinson-Patman Act prohibited any rebates which had the effect of lessening competition or creating a monopoly. ${ }^{25}$ Patronage dividends having that effect would be prohibited by the Act if they were in any sense trade discounts, rebates, or price adjustments. However, the Robinson-Patman Act further provides:

Nothing ... [in this Act] shall prevent a cooperative association from returning to its members, producers or consumers the whole, or any part of, the net earnings or surplus resulting from its trading operations, in proportion to their purchases or sales from, to, or through the association. ${ }^{26}$

The United States Treasury Department recognizes that cooperative corporations make profits. Its report on the taxation of farm cooperatives, issued in October, I947, states:

A successfully operated farm cooperative will ordinarily produce some economic income over a period of years, especially if it uses any significant amount of capital and assumes any significant amount of risk. ${ }^{27}$

Whether the Treasury Department regards patronage dividends as rebates or price adjustments or whether it regards them as distributions of corporate profits (economic income) may be found from a Department ruling which concerned an incorporated fruit growers' association that conducted its business at a profit. The Treasury Department ruled that this non-exempt corporation would not have to pay any income tax on its patronage dividends. It authorized the corporation to:

... deduct from gross income amounts periodically returned to members as a refund of profits on business transacted with them and proportioned to the amount of such business. ${ }^{28}$

The Treasury ruling does not say that cooperative corporations do business at cost, or that because of price adjustments they have no net income. It does rule, however, that when this net income is distributed to the patron-members of the corporation as a patronage dividend, it will be permitted to escape the corporate income tax.

The position of the Tax Court with respect to funds distributed as patronage dividends may be determined from its language in United Cooperatives, Inc., ${ }^{20}$ decided in 1944. Referring to dividends on the cooperative's common stock, the court said:

After a careful consideration of petitioner's charter and bylaws, we conclude that petitioner's patrons were entitled as of right to a distribution of petitioner's net income

${ }^{25} 49$ STAT. 1528 (1936), 15 U.S.C.A. \$13(a) (1941).

2049 STAT. 1528 (1936), I5 U.S.C.A. \$13(b) (1941). (Italies supplied.) Similar treatment was accorded patronage dividends under the OPA. See pars. 4 and 5, subsection (c), $\$ 1305.215$, SopplEMentaRY ORDER No. 84, 9 Fed. Reg. 1721 (r944) and under the Commodity Exchange Act, 49 StaT. I49I (1936), 7 U.S.C. \$I et seg. (1940).

"U. S. TREASURY Dep'T ReP. 6 (October, 1947).

2 O. D. 64 , I CUM. BULL. 208 (1919). (Italics supplied.)

" 4 T.C. 93 (I944). 
as defined by article VI of its bylaws as so-called patronage dividends without further corporate action on petitioner's part, and that the corporate resolutions set out in our findings merely recognized and confirmed the rights which the patrons already had, in so far as they refer to the net income of petitioner available for distribution to its patrons after the payment of dividends on petitioner's common stock. . . .

These dividends, if paid, would be paid out of net income. If dividends were not paid, then the net income of the petitioner available for distribution to its patrons would be accordingly greater. The choice of whether so much of its net income as equaled $8 \%$ of the par value of its common stock should be distributed to its stockholders as a dividend or to its patrons as rebates was in the corporation. ${ }^{\mathbf{3 0}}$

The Tax Court terms that which is available for distribution to patrons "net income of the petitioner." This "net income" can be distributed to the stockholderpatrons either on the basis of their stock holdings, or on the basis of their patronage, or on the basis of both. No price adjustment is involved which would prevent the corporation from having any income to distribute on the basis of patronage.

As a result of a long-established practice of the Treasury Department, patronage dividends of cooperatives are, in the main, not taxed. This tax exemption has also been sanctioned by the Board of Tax Appeals. There are also three or four more or less conflicting opinions (not quite in point) at the circuit court of appeals level..$^{31}$ The question has never been before the Supreme Court.

An excellent example of how the Treasury practice is sanctioned by the Board of Tax Appeals is found in the leading case of Midland Cooperative Wholesale $v$. Commissioner. ${ }^{32}$ That case involved a super-cooperative corporation, the members of which were local cooperative associations. This super-cooperative operated gasoline service stations and sold automobile accessories and supplies. It was organ. ized under the ${ }^{2} 23$ Minnesota Cooperative Law, ${ }^{38}$ which contained the following provision regarding "Earnings, Reserves, and Patronage Dividends":

Net income in excess of dividends on capital stock and additions to reserve and surplus shall be distributed or credited on the basis of the quantity or value of the commodities handled for each patron. 34

In December, I937, the board of directors approved a resolution providing for "the disposition of the net earnings for I937." This resolution provided that 50 per cent of the "net earnings" should be placed in a "Patrons' Equity Reserve."

The question before the Board of Tax Appeals was whether or not that part of the net earnings which had been placed in the "Patrons' Equity Reserve" should be subject to the corporate income tax. In approaching the problem, the Board first

${ }^{20} I d$. at 10\%, ro8. (Italics supplied.)

${ }^{81}$ Farmers Union Coop. Co. v. Commissioner, 9o F. 2d 488 (C.C.A. 8th r937); Cooperative Oil Ass'n v. Commissioner, II5 F. 2d 666 (C.C.A. gth 1940); American Box Shook Export Ass'n v. Commissioner, I56 F. 2d 629 (C.C.A. 9th 1946); San Joaquin Valley Poultry Producers Ass'n v. Commissioner, 136 F. $2 d 382$ (C.C.A. 9th 1943).

244 B.T.A. 824 (194).

"Laws of r923, C. 326,57 .

"Ibid. 
noted that Congress had not provided for the deduction of patronage dividends from the gross income of a cooperative association. It went on to say:

The Treasury Department, however, ... . with "great liberality" has allowed such deductions "to the end that substantial justice may be done to an association which is engaged in cooperative marketing or purchasing work but which may not be exempt from taxation."'35

The Board therefore allowed the deduction.

In this case, Midland also sought credit for purposes of the surtax imposed by Section 14 of the Revenue Act of 1936,86 because in accordance with the state law under which it was organized, its corporate by-laws, and the resolution adopted by its board of directors, it had distributed its net income to its stockholders and patrons. The Board of Tax Appeals, however, refused to agree that it had thus distributed its income and commented on the contention that it had done so as follows:

It is also not inappropriate to point out that petitioner's contention that the "net income" of a corporation is being "distributed," if-sustained, would deprive it of the deduction of the amounts paid to its members or allocated to them upon its books; for such deductions may be allowed only upon the theory that the distributions were rebates upon the business of the members rather than income of the association. ${ }^{37}$

The Board of Tax Appeals exercised "great liberality" in order to permit this income to escape the corporate income tax.

According to the courts, the only reason for not taxing patronage dividends at the corporate level is that the corporation earns them under an obligation to distribute them to patrons. Patronage dividends paid in the absence of such an obligation to distribute are considered part of the corporate net income and are taxed to the corporation. ${ }^{38}$

In holding that patronage dividends not paid because of an obligation to distribute them are taxable at the corporate level, the courts use reasoning similar to that used by the Tax Court in American Box Shook Export Association v. Commissioner, ${ }^{30}$ where the court said:

The taxpayer points to no statute authorizing the claimed deductions. Clearly they are not deductible expenses. The petitioner was under no obligation to make distributions to its members until the board of directors had so acted.40

On the other hand, when the corporation has by-laws or a charter directing

${ }^{35}$ Supra note 32 , at 830 .

${ }_{53}^{80}$ STAT. 8 (1939), as amended, 26 U.S.C. \$I4 (1940).

${ }^{87}$ Stupra note 32, at 835 .

${ }^{88}$ Fountain City Cooperative Creamery Ass'n, 9 T. C. No. I40 (I947); American Box Shook Export Ass'n v. Commissioner, 156 F. 2 d 629 (C.C.A. 9th 1946); Druggists Supply Corporation, 8 T. C. x343 (x947); Peoples Gin Co. v. Commissioner, II8 F. 2d 72, aff'g 4I B.T.A. 343 (C.C.A. 5th I94I); United Butchers Abattoir, Inc., 5 T.C.M. 40 (1946); Farmers Union Cooperative Elevator Ass'n, 4 T.C.M. 490 (1945); Farmers Union State Exchange ef al., 30 B.T.A. I051 (1934); of. Juneau Dairies, Inc., 44 B.T.A. 759 (1941); Clay Sewer Pipe Ass'n v. Commissioner, I39 F. 2d I30 (C.C.A. 3d 1943).

${ }^{30} 4$ T. C. 758 (1945).

${ }^{10}$ Id. at 763 . 
the distribution of patronage dividends, the income so distributed is allowed to escape taxation because it is paid in pursuance of a legal obligation.

The nature of the change from corporate net income into an exclusion or deduction from gross income is clearly shown in Peoples Gin Company v. Commissioner.1 In this case, a business corporation incurred an obligation to pay patronage dividends after profits had been determined. Concerning this patronage dividend, the Board said:

Such a distribution constitutes the payment of a dividend and is not deductible in determining the petitioner's net income. The fact that the profits were distributed to stockholders on some basis other than the stock held by each stockholder does not make the distribution any the less a dividend. ${ }^{42}$

Subsequently, the Peoples Gin Company made anticipatory by-laws and contracts with respect to the income it expected to earn in the future. The effect of these anticipatory contracts and by-laws was to assign its net income to its stockholders in proportion to their patronage.

The Commissioner again attempted to tax the company's patronage dividends at the corporate level. The Tax Court pointed out that the written agreements entered into by the corporation obligated it to make the payments involved and decided that it was therefore entitled to deduct them from its gross income. ${ }^{43}$

The point sharply presented is: Do profits distributed to stockholder-patrons, admittedly non-deductible in the absence of a pre-existing obligation, become deductible merely by virtue of the existence of such an obligation?

Cooperative leaders, since the case for the non-taxability of their corporate carnings depends upon it, are forced to maintain that this question should be answered in the affirmative, and it is true that the eddy in the law caused by the Tax Court's acceptance of the "great liberality" of the Treasury Department supports their position. When we get away from this great liberality, however, and examine the principles of law which apply to the taxation of income, we find case after case involving all types of factual situations in which the courts have held time and time again that the existence of such an obligation does not prevent the profits from being taxable to the person or corporation earning them. Persons and corporations have frequently entered into anticipatory contracts and trust agreements governing income to be earned in the future. When such income is earned and distributed in accordance with the contractual obligation, a question arises whether it should be taxed to the person or corporation earning it, to the person or corporation receiving it, or to both. Basically, the question is one of assigned income.

The leading case on this subject is Lucas v. Earl, ${ }^{44}$ in which Earl and his wife agreed in Igor that any profit that they might receive would be held by them as joint tenants. The validity of the contract was not questioned; yet the Court held

${ }^{21} 41$ B.T.A. 343 (1940).

"Id. at 347,348 .

ts Peoples Gin Co., 2 T.C.M. 325 (1943).

“28I U. S. III (1930). 
that all of Earl's earnings were taxable solely to him, even though they were not all beneficially received by him. Concerning the income tax, the Court said:

... the tax could not be escaped by anticipatory arrangements and contracts however skilfully devised to prevent the salary when paid from vesting even for a second in the man who earned it. 45

The Court disregarded "the arrangement by which the fruits are attributed to a different tree from that on which they grew." 46

The principle of law involved is well set out in the following language from Saenger v. Commissioner: 47

The rule of the Earl Case, while made graphic by a figure, is more than a figure of speech. It is an expression of the simple truth that earned incomes are taxed to and must be paid by those who earn them, and unearned incomes to those who own the property or right that produced them, not to those to whom their earners or owners are under contract to pay them. It establishes once for all that no device or arrangement, be it ever so shrewdly and cunningly contrived, can make future earnings taxable to any but the real earner of them, can make future incomes from property taxable to any but the owner of the right or title from which the income springs. ${ }^{48}$

In other words, when a cooperative corporation enters into marketing contracts with its patrons, which provide that the profits of the corporation shall be distributed to the patrons on the basis of their patronage, the earned incomes of that corporation "are taxed to and must be paid by those who earn them and ... not to those to whom their earners or owners are under contract to pay them."

A factual situation having much in common with that of marketing cooperatives existed in Fontana Power Company v. Commissioner. ${ }^{49}$ In that case, the taxpayer, a public utility corporation, acquired certain operating properties in exchange for all of its stock and agreed to pay to the sellers, the difference between the value of the stock it issued to them and the value of the properties it received, the value to be determined later. Pending this determination, the taxpayer contracted and was obligated to pay to the sellers all of its net profits. These profits, received by the sellers, were regarded as part payment to them of the properties sold, exactly as the patron-member of a marketing cooperative claims the corporate profits he receives in patronage-dividend form are payment in part for the produce he has previously sold to the corporation. The Board said:

Neither are we impressed by petitioner's argument that the payments involved here, made by petitioner to its stockholders for so many years, cannot be considered as distributions in the nature of dividends because (I) they were made pursuant to a contract and not pursuant to the rights of the payees as stockholders, and (2) the distributions consisted of the net earnings and not the surplus profits technically available for dividends. ${ }^{.0}$

${ }^{18}$ Id. at 115 .

699 F. 2d 63 I (C.C.A. 5th I934).

$\therefore 43$ B.T.A. I090 (194I), aff'd, I27 F. 2d I93 (C.C.A. 9th 1942).

so Id. at 1097. (Italics supplied.)
4 Ibid.

" $l d$. at 632. (Italics supplied.) 
Referring to the contractual-obligation argument of the taxpayer, the Board said:

The practical effect of the transactions was to distribute an amount equivalent to the net profits of petitioner to its stockholders. ${ }^{51}$

The Board held for the Commissioner. The circuit court of appeals affirmed, ${ }^{52}$ holding that the corporate income was taxable to the corporation earning it, even though it was distributed under a contractual obligation, because the petitioner could point to no statute authorizing the deduction it sought. Thus the fact that distributions are made pursuant to a contract and on a basis of patronage rather than the rights of the payees as stockholders should have no effect on the obligation of the corporation to pay an income tax on the profits it distributes in accordance with its contractual obligations.

Similar reasoning was followed by the circuit court of appeals in Cooperative Oil Association v. Commissioner. ${ }^{53}$ In that case the Commissioner, instead of following the long-established bureau practice, sought to tax at the corporate level cooperative net income, the distribution of which as patronage dividends was tem. porarily postponed to provide the corporation with working capital. The cooperative had been incorporated as a non-profit cooperative association under the laws of Ohio. ${ }^{54}$ The by-laws of the corporation provided that its net income, except such amounts as by law or by the Board of Directors might be set aside as reserve funds, should be distributed to the stockholding patrons on the basis of their patronage. Before the court, the cooperative contended that its articles and by-laws specifically made its earnings belong to its members so that it did not earn profits for itself as a taxable entity but only for its members. Outside of the administrative practice of the Treasury Department, the court could find no provision in the statute which would allow patronage dividends to escape taxation. Answering the contentions of the cooperative and ruling in favor of the Commissioner, the court said:

In other words, petitioner points to no statute authorizing any deduction whatever, and we are in effect asked to hold that a practice of respondent permitting a deduction not authorized by statute, is not liberal enough. We know of no manner in which such liberality may be reviewed in this court... Whether respondent should have allowed the deduction he did allow is a question upon which we express no opinion.55

Since no issue was before the court with respect to the deduction allowed by the Commissioner for income actually distributed as patronage dividends, it would have been improper for the court to point out that its reasoning was equally applicable to the deduction allowed with respect to such funds. Surely cooperatives seeking to escape income taxes on that part of their income distributed as patronage

${ }^{81}$ Ibid.

"See note 49 supra.

ss II5 F. 2d 666 (C.C.A. gth 1940).

s"The Ohio Code relating to such associations provided: "Associations organized hereunder shall be deemed "non-profit inasmuch as they are not organized to make profits for themselves, as such, or for their members, as such, but only for their members as producers." Orno Gen. Code ANN. fror86.x.

${ }^{85}$ II5 F. 2d 666, 668, 669 (C.C.A. 9th 1940). (Italies supplied.) 
dividends should also be required to point to an applicable statute and show that they come within its terms. But, since Congress did not authorize a deduction for income distributed as patronage dividends, cooperatives are forced to rely solely upon the great liberality of the Treasury Department and the acceptance of that liberality by the Tax Court. In fact, as a matter of law, it is difficult to see why the net income of a non-exempt cooperative corporation is not subject to the corporate income tax, even though some or all of it is distributed to its stockholding patrons in the form of patronage dividends.

In Raybestos-Manhattan, Inc. v. United States, ${ }^{56}$ the Supreme Court said:

Income is not any the less taxable income of the taxpayer because by his command it is paid directly to another in performance of the taxpayer's obligation to that other. ${ }^{67}$

It follows that if patronage dividends are paid from the income of a cooperative corporation in order to comply with its charter or by-laws, and in order to settle an obligation of the cooperative to its patrons, then the patronage dividends should be taxable to the cooperative corporation.

Balkwill v. Commissioner 58 dealt with the taxability of income from a partnership interest which had been placed in trust. In applying the principle under consideration the court said:

... the person who receives income is not relieved from the tax because he chooses not to enjoy it; and this' is not necessarily changed by the fact that he is deprived of the income by a legal obligation. ${ }^{50}$

Comer $v$. Davis $^{60}$ concerned a trust agreement and the distribution of future earnings thereunder. The Commissioner disregarded the contractual obligations involved and taxed the trustees on the money they earned whether they had a right to retain it or not. In sustaining the position of the Commissioner, the court said:

It is well established that earned income is taxable to those who earn it, notwithstanding a contractual disposition after it is received. The statute here involved so levies the tax, and to question appellant's liability therefor is not so much a matter of statutory construction as a challenge to the power of Congress to levy the tax against the person who owns the income. ${ }^{61}$

The Board of Tax Appeals has also disregarded the contractual-obligation theory without hesitation when an ordinary business corporation was involved. ${ }^{62}$

Porter Royalty Pool, Inc. v. Commissioner ${ }^{63}$ concerned a corporation which, like a cooperative corporation, had a by-law that required it to make a distribution of its income. In trying to avoid the payment of income taxes upon the income distributed in accordance with its contractual obligations, the corporation used the

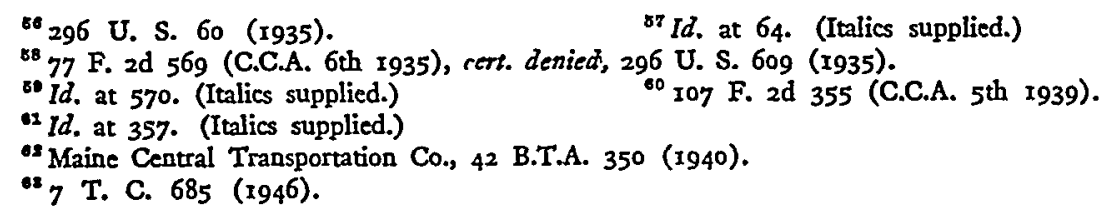


same arguments that cooperative corporations use to justify their escape from a similar tax liability. The corporation's arguments are set out in the opinion as follows:

... the petitioner contends that the sums in question were not its income but were the income of its stockholders. It contends that under its articles of incorporation and by-laws the petitioner was empowered only to collect the royalties and was required to distribute them monthly to the stockholders after deducting expenses and the sum of \$200 which was required to be retained in the treasury; that it could use the royalties for no purposes of its own; could not engage in business; and that, therefore, it had no proprietary right, title, or interest to the moneys received but received them only as trustees or agents for its stockholders. ${ }^{\text {B }}$

The Tax Court refused to be swayed by the above arguments and, holding the corporation to be taxable on the income it was obligated to distribute, referred to Moline Properties v. Commissioner. ${ }^{65}$ There the Supreme Court referred in the following language to Burnet v. Commonwealth Improvement Company, ${ }^{6 B}$ where a corporation had been held taxable for a profit on a sale to its sole stockholder:

This was because the taxpayer had adopted the corporate form for purposes of his own. The choice of the advantages of incorporation to do business, it was held, required the acceptance of the tax disadvantages. ${ }^{67}$

The members of an incorporated cooperative association have chosen to use the corporate form of doing business. The fact that by contractual arrangements the corporate income goes not to the corporation but to its patron-stockholders is irrelevant as far as the taxation of that income to the corporate entity is concerned. When the corporate members accept the advantages of incorporation, they are also required to accept the tax disadvantages.

The mere fact that the cooperative purports to act as agent for its members does sot warrant its tax exemption. A corporation can transfer its earnings in only two ways: by gift and by contract. Neither of these transfers will affect the income-tax liability of the corporation on the earnings so transferred. When a corporation uses its own business judgment in its business operations it is acting as a principal and is taxed as a principal even though it does not treat its earnings as its own because it is acting under an agency contract. ${ }^{\text {es }}$

Cooperatives also argue that the part of their net income which they are obligated to distribute as patronage dividends cannot be taxed to them because they have no control over such funds. They direct attention to the fact that they are bound by charter provisions or by by-laws which they have previously adopted and so do not have free control over the disposition of their income.

An example showing how little control is necessary to make income taxable to the former owner is found in United States v. Joliet \& Chicago Railroad Com-

Id. at 697 .

os 287 U. S. 415 (1932).

os 3 I9 U. S. 436 (1943).

Br 3 I9 U. S. 436,439 (1943).

"All Russian Textile Syndicate v. Commissioner, 62 F. 2d 6r4 (C.C.A. 2d 1933), cert. denied, 289 U. S. 752 (1933). 
pany. ${ }^{69}$ The plaintiff in that case, the owner of thirty-seven miles of railroad between the cities of Joliet and Chicago, Illinois, on January I, I864, entered into an indenture under which it granted, demised, and leased the railroad, together with all the appurtenances thereof, to the Chicago \& Alton Railroad Company, its successors and assignees, without reservation, forever. In consideration therefor, the Chicago \& Alton Railroad Company obligated itself to pay to the plaintiff's stockholders forever, in quarterly installments, an annual dividend of 7 per cent per share on the par value of all outstanding capital stock.

Although the plaintiff corporation remained in existence only to maintain a stock-transfer book, the Commissioner asserted a tax against it on the basis that the income received by its stockholders was income to it. The taxpayer pointed out that the so-called lease in perpetuity without a defeasance clause divested it of all right, title, and interest in the property and vested a full and indefeasible title in the grantee. The taxpayer also called attention to the fact that the indenture of I864 vested all rights to payment of dividends in its stockholders and divested it of any right to, or control over, such payments. The taxpayer therefore contended "that a corporation which does not own or control property and has no right to, or control over, any income from the property cannot be in receipt of income, constructively or otherwise."70 In sustaining the Commissioner, the Court said:

Such considerations do not dispose of this controversy.... The fact that there is an anticipatory arrangement whereby the taxpayer is not even a conduit of the payments is no more significant in this type of case than it was in Lucas v. Earl, supra. ${ }^{71}$

In a footnote to Commissioner v. Tower, ${ }^{72}$ the Supreme Court referred to the Joliet \& Chicago Railroad case, saying:

Under some circumstances, income has been held taxable to a person even when he does not own or control it. ${ }^{73}$

The fact that a cooperative corporation has no immediate right to or control over the income which it distributes as a refund to its patrons does not mean, therefore, that it should escape the corporate income tax with respect to such monies.

\section{III}

The above review of cooperative statutes, charters, by-laws, Treasury rulings, and court decisions demonstrates that "patronage dividends," as that term is commonly used by the cooperatives, are distributions of net income on a patronage basis. Various principles of income tax law, when applied to cooperative corporations, also indicate that patronage dividends should be included in their taxable income.

The cooperatives maintain that patronage dividends are additional price adjustments, or rebates, or price payments, in order to justify their escape from taxation.

${ }^{\circ 9} 315$ U. S. 44 (1942).

${ }^{71} I d$. at 46,48 . (Italics supplied.)

${ }^{78}$ Id. at 289 n. 7 (Italies supplied.)
${ }^{70}$ Id. at 46 .

${ }^{72} 327$ U. S. 280 (I946). 
It is true that any money received from a business because of patronage may superficially be regarded as a price adjustment. When that so-called "price adjustment" is keyed to, and acts to distribute corporate profits, however, it must be considered as corporate net income for purposes of income taxation.

The cooperatives contend that they handle a patron's business on a non-profit agency basis. Because of the large size of their operations, however, they do not and cannot operate that way. Inherent difficulties make it economically unwise, if not impossible, for them to act as agents, or to foresee economic conditions accurately enough to enable them to operate on a cost basis. As a result, they have to operate on a profit basis in the same way that any other business corporation does. Thus cooperative practice fails to follow cooperative theory. The cooperatives try to get back to the non-profit basis by the method in which they distribute their taxable income. Since the substituted method is not the original ideal, however, they do earn profits and so should be taxed on them. Moreover, the patronage dividend paid to any particular member has no relation to the profits made on transactions with him, and thus can be regarded only as a pro rata distribution of over-all profits.

The cooperative does not act as the true agent of any particular patron. When a patron makes a sale of commodities to the cooperative or a purchase of goods from it, title to such commodities or goods passes to the purchaser upon execution of the sale in both instances. After a marketing cooperative purchases the commodities, acquiring title thereto, it treats the commodities as its own, commingling such commodities with those of others, mixing, processing, handling, and in some cases manufacturing them without any requirement that an individual accounting be made to each patron for each particular commodity handled. In many cases, incidental services are also performed. Because of the natural uncertainties of business, losses may occur in some commodities and gains in others. With respect to transactions with a particular patron, losses may occur on some or all transactions, while with another patron the transactions may be consistently profitable.

In the case of purchasing or consumers' cooperatives, usual business practices are followed with respect to accumulation of inventory. Market prices are determined by reference both to general marketing conditions and cost of inventory acquisition. As in the case of marketing cooperatives, numerous incidental services are performed.

A general analysis of the business operations of cooperatives reveals the impracticability if not the impossibility of relating patronage dividends to gain or loss upon any particular transaction with any particular patron.

To say, in effect, that a sale remains open until the end of an accounting period to permit the payment of an addition to the price does not recognize facts. For example, during 1946 there were extremely wide fluctuations in the price of flaxseed, the price increasing from $\$ 3.00$ to $\$ 6.00$ per bushel in just a few days. Many farmers sold flaxseed to cooperative grain elevators both before and after the price increase. In the case of a farmer who before the price increase sold flaxseed which the co- 
operative sold after the price increase, the theory that the former sale was not closed but was in fact open pending receipt of the additional price would require that an additional payment of almost $\$ 3.00$ per bushel be made. The farmer who had received $\$ 6.00$ initially and whose flaxseed was sold by the cooperative at $\$ 6.00$ plus freight and margin would not be entitled to receive additional payment. But cooperative corporations do not return to each farmer the net proceeds of the sales of his produce less necessary expenses; instead, they determine the over-all net profits for flaxseed and these profits are shared by all flaxseed patrons in proportion to their patronage.

The fact that cooperatives do not, by patronage dividends, adjust their prices so as to do business at cost is clearly seen in the case where transactions with a particular patron result in a loss. Assume, for example, that one patron sold only durum wheat to the cooperative, all of which was disposed of at a loss. The greater the patronage of this member, the greater is the cooperative's loss on his business, and paradoxically, the greater is his share in the cooperative's over-all net profit.

The fact that a patronage dividend is not a mere price adjustment which enables a cooperative to handle specific business transactions at cost is thrown into sharp relief where the patronage dividend is more than the commission originally charged. For example, the Eighth Annual Report of the Farmers Union Grain Terminal Association states:

You will note that your patronage savings from FUGTA are more than the commission rate which we must charge. This means the producer not only gets a patronage refund equal to the full commission charged but also a fraction of a cent a bushel in addition. The additional savings were made possible by the processing, storing and merchandising of your grain through the terminal facilities.

This excerpt discloses that the Farmers Union Grain Terminal Association did not merely handle the farmers' produce at cost. The size of its patronage dividend was so large that, in effect, this cooperative not only handled the farmers' produce for nothing but apparently paid him for putting it to the trouble of marketing his produce.

Actually, of course, no price adjustment bringing services down to a cost basis was involved. A patronage "saving" that saves more than it started with is patently more than a "saving." There must have been income to pay for operating expenses and to provide for the payment made to patrons in addition to the return of the commission charged. In fact, the cooperative has simply distributed over-all profits, and in so far as the price-adjustment theory holds otherwise it is unrealistic.

A consumers' cooperative during its fiscal year sells myriads of different kinds of articles to members and non-members indiscriminately at varying profit marginssome at a loss. A particular patron during the year may buy varying quantities of many different items, from soap, cosmetics, tooth paste, drugs, electrical appliances, corn flakes, and cigarettes to tractors, hay ricks, pumps, rope, and fence wire-each at a different profit margin to the cooperative. He may confine his purchases to 
the grocery department, which shows an over-all loss, and be entitled to a patronage dividend only because of large profits in the farm-machinery department. It is obvious that what the member receives at the end of the year is not the profit that the cooperative made on its transactions with him, but a share, fixed in a wholly arbitrary and completely unrealistic fashion, of the cooperative's total yearly profits, including its profits from collateral sources.

A further example will illustrate the true nature of the patronage dividend. A cooperative may maintain branches in town $A$ and town $B$. Because of inefficient management or lack of sufficient volume at town $B$ a net loss for the year may be incurred by the branch there, while a profit may be realized at the branch in town $A$. The patronage dividend paid to members dealing with the branch in town $B$ represents nothing but a shifting to them of profits on transactions with an entirely different set of customers in town $A$. It is thus an absurdity to call the patronage dividend paid to the members in town $B$ an adjustment to the price of produce already handled by that branch at a loss.

Cooperative spokesmen apparently have believed that if they could describe patronage dividends as being a kind of price adjustment (i.e., an additional or final payment to the farmer for his produce; or, in the case of purchases, the return of excess charges made over actual cost to the cooperative) they would have justified the escape of patronage dividends from corporate income taxes.

Analysis of this theory shows that such is not the case. A patronage dividend can be a final payment to the farmer for his produce or the return to him of excess charges over the cost of supplies purchased by him and still be distribution of corporate income.

This fact has been particularly recognized by Treasury rulings and by the courts in those cases in which cooperative corporations, doing business with members and non-members, pay patronage dividends to members only. In those cases, the cooperative corporation makes its final payment to the farmer for his produce, or returns to him overcharges made on supplies furnished to all in accordance with good cooperative theory, and yet those "price adjustments" are considered as distributing, in part at least, corporate income on which the cooperative must pay a tax.

Thus a Treasury ruling states:

Profits made by the company upon sales to nonmembers constitute taxable income, irrespective of the fact that such profits were returned to members by reduction of cost or otherwise. ${ }^{74}$

In this ruling, the Treasury held that a reduction of cost (price adjustment) was in essence a distribution of profits because the amount thereof was determined by the net profits. Since "price adjustments" may be used to siphon net profits out of the corporate entity, they are examined with great care and should be disallowed

"S.M. 2595, III-2 Con. Bur.. 238 (1924). (Italics supplied.) 
for income-tax purposes when they are based upon, and in effect distribute, corporate profits.

The courts in other similar situations have also refused to be bound by the price adjustment theory, and have investigated the source of the funds distributed as patronage dividends in order to determine whether or not the so-called "price adjustment" was also a profit distribution made on a basis of patronage.

In Juneau Dairies, Inc. v. Commissioner, ${ }^{75}$ the Board of Tax Appeals under such circumstances refused to allow the price-adjustment theory to decrease corporate income taxes. With respect to the contracts controlling the price adjustments or refunds, the Board pointed out that:

The contracts were made by the shareholders with an entity of their creation, an organization operated and controlled by them.78

Since it was the owners of the cooperative who were receiving the price adjustment, the Board of Tax Appeals considered the funds distributed as a price adjustment to be a dividend, pointing out that:

... a distribution of profits may be made on a basis other than stockholdings and still be a dividend distribution. ${ }^{37}$

In other words, profits may be distributed as a final payment made for produce furnished by a patron, and still be a distribution of profits on which the corporation must pay a tax.

In Fruit Growers Supply Company v. Commissioner ${ }^{78}$ a cooperative paid patronage dividends only to members although it also did business with non-members. The cooperative maintained that a patronage dividend was a price adjustment on members' produce and that when it computed its income, using the adjusted price, it had little, if any, income earned as a result of its transactions. The court refused to allow these "price adjustments" to decrease the income-tax liability of the corporation on the profits distributed thereby. Referring to the income from nonmember business, the court said:

The fact that under the terms of its organization and its method of conducting business this income would go to its members in proportion to the amount of goods purchased by them instead of in proportion to the stock held by them, does not alter the fact that the amount received is in the nature of a profit and therefore, income, to be distributed in accordance with the form of organization of the corporation.... We cannot believe that the method by which this income is distributed to the members detracts in anywise from the fact that the profit is essentially an income to the corporation, and we believe, and hold, that the Board of Tax Appeals correctly determined this question.79

While the distinction between a patronage dividend and a price adjustment was recognized, it was not carried to its logical and reasonable conclusion. If it were, there would be no issue today as to treatment of patronage dividends.

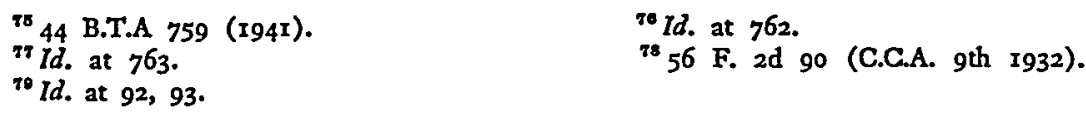


This can be illustrated by assuming a case in which a patron-member of a cooperative limits his purchases during the year to "loss leaders." On each of his purchases, as well as on all of his purchases in the aggregate during the year, the cooperative will actually suffer a loss. Yet the patron will be entitled to a patronage dividend, which can be paid to him only out of profits which the cooperative makes on its transactions with other patrons. The difference in treatment between a distribution to him of profits made on transactions with other members and a distribution to him of profits made on transactions with non-members is wholly irrational, for there is no difference in principle.

Taxation is an intensely practical matter. Since it is concerned with economic realities, these should be examined. The business operations of a cooperative corporation are similar to those of a proprietary or business corporation. Although organized for cooperative purposes, a cooperative is a separate legal entity, distinct from its members and shareholders. The business corporation operates through the agency of its paid officers and employees; the cooperative corporation operates in the same way. The business corporation has capital stock divided into shares; so has the ordinary cooperative. As opposed to partnerships, both business and cooperative corporations have a continued existence which is not affected by the death, bankruptcy, or personal conduct of members.

The profit of a business corporation is arrived at by finding the margin of gross receipts over necessary costs and expenses. The cooperative's profits or savings are arrived at in precisely the same way. In both, the net income or savings is money surplus, and the profits will depend on market conditions, working capital, and the loyalty and diligence of officers and employees. In neither type of organization are the members or shareholders liable for the debts of the corporation except to the extent of the amounts unpaid on their memberships or shares. In neither is the individual member or shareholder entitled to the surplus or reserve, or any part thereof, until the directors have declared a dividend in accordance with the state law and the charter and by-laws of the corporation.

When comparisons are made, it is clear that cooperative corporations possess all of the essential attributes of ordinary business corporations except as to the basis of distribution of their net earnings. The business corporation usually divides part of its profits among its shareholders in proportion to the shares owned. A cooperative corporation, after distributing part of its profits to its shareholders in the form of a dividend not exceeding 8 per cent, distributes the rest in proportion to the volume of the members' purchases or sales.

The cooperative corporation has full command of its profits. As stated by the circuit court of appeals in Farmers Union Co-op. Company v. Commissioner:80 Clearly this money is property of the corporation as genuinely and truly as is the grain elevator or the stock of merchandise owned by it. While those who might be entitled to patronage dividends have, in a sense, an interest in the money it is a character of interest not greater, if as great, as that of a stockholder in an ordinary corporation. ${ }^{81}$

${ }^{80}$ go F. 2 d 488 (C.C.A. 8th 1937).

id Id. at 49 I. 
The court pointed out that this cooperative had the standard provisions in its by-laws with respect to the payment of dividends upon capital stock, and held that this was a feature of private profit from the enterprise. It concluded:

Such being the situation here, we must conclude that this balance of income over outgo in 1928 was a gain subject to taxation under the Sixteenth Amendment. ${ }^{82}$

These considerations point inevitably to the conclusion that the patronage dividends distributed by a cooperative corporation are in the usual case distributions of corporate income which only superficially resemble refunds or additional price payments. This conclusion is founded on reasoning as welt as on legislative, judicial, and administrative authority. Since patronage dividends are distributions of corporate profits, they should not escape corporate income taxes. Because of the keen competition between corporations in our business economy, the power of cooperative corporations to dodge payment of income taxes on all or a part of their income gives them, in this era of high taxation, a tremendous competitive advantage-an advantage which, unless checked, threatens the very existence of regular tax-paying corporations.

sId. at 492. 